Studia Anglica Posnaniensia 51/4, 2016

doi: 10.1515/stap-2016-0018

\title{
REPETITION AS TRAPPED EMOTION IN TENNESSEE WILLIAMS'S THE GLASS MENAGERIE
}

\author{
Olivera Kusovac and Jelena Pralas ${ }^{1}$
}

University of Montenegro

\begin{abstract}
Repetition as a linguistic and stylistic device extensively used in Tennessee Williams's plays has been noticed by many. At the same time, more psychologically-inclined scholars have frequently drawn parallels between Williams's plays and his own experiences and emotional conflicts. In an attempt to combine the two perspectives, this article will explore the function of repetitions as indicators of trapped emotions in Williams's celebrated and award-winning play The Glass Menagerie. Starting from the stylistic theoretical background, but at the same time taking into account the psychological insights into the link between Williams's life and work through some basic concepts of Freud and Lacan, an attempt will be made to demonstrate that in this play linguistic repetition appears as an obsessive expression of the characters' emotions as well as those of the dramatist himself, making him repeat and relive both his experiences and his emotions. The authors will first introduce the concept and functions of repetition as a linguistic and stylistic device and then explore its representative instances in individual characters and their meanings, ending with the parallels which can be drawn between the characters' and the dramatist's own experiences and emotions expressed or intensified through repetitions.
\end{abstract}

Keywords: Tennessee Williams, The Glass Menagerie, repetition, repetition compulsion, trapped emotions

Repetition as a linguistic and stylistic device is used in many plays by Tennessee Williams, one of the greatest twentieth century American dramatists rivalled only by Eugene O'Neill and Arthur Miller (Kolin 1998: ix). This has not passed unnoticed, either among scholars who have seen his characters and plays as

Corresponding authors: Faculty of Philology, Jovana Tomaševića 37, 81000 Podgorica, Montenegro, University of Montenegro, email: oliverak@t-com.me, pralas@t-com.me. 
"fountains of ... blistering, nerve-scraping, recognizable speech" (Kerr 1996: 118 ), or among those who have primarily been tempted to explore the superb and distinguished dramatic style of the playwright. And his style, apart from exhibiting an unparalleled variety of idiolects and sociolects, is widely recognized for its poetic expressions, lyricism and the liberation of words, demonstrating "the joy of the writer in writing them", which made a link "to the whole tradition of unashamed word-joy" (Miller 1987: 182). A very illustrative example is Dan Isaac's (1965) exploration of repetition in the celebrated, Pulitzer winning piece Cat on a Hot Tin Roof. In it, Isaac presents one of the main characters of this play, Big Daddy, a dying patriarch whose fortune is the cause of family strife, through his use of language and (poetic) repetition. Notably, posing the question as to how Big Daddy succeeds in "arousing the emotion of the audience to such a high pitch of admiration and active concern" (Isaac 1965: 272), he attempts to show that the explanation lies in his use of language. Analysing his language, Isaac mostly focuses on the repetition of words, phrases and, eventually, word strings, which he sees as Williams's "most forceful rhythmic device" and which seem to "grow and lengthen because of an unusual energy released by the increasing excitement of the rhetorical device in progress" (Isaac 1965: 273). It is in these repetitive word strings that he finds the main driving force behind the tremendous poetic and emotional effect the character of Big Daddy creates in the readers of this play.

However, not all scholars have focused on repetition in Williams's plays as a linguistic and stylistic device. Joseph Silvio (2002), for example, speaks of the dramatist and his work from the psychoanalytic perspective with an emphasis on Freud's concept of repetition compulsion, focusing in particular on another masterpiece by Williams, A Streetcar Named Desire. Presenting the relevant biographical information about the dramatist, this scholar finds a striking and profound link between his troubled childhood experiences and relationships and the "contrasting themes, characters, and action" (Silvio 2002: 135) both in this play and in The Glass Menagerie. Illuminating the depth of his psychological conflicts and emotional turmoil, Silvio accentuates Williams's inability to leave behind family problems: "secrets of drunken rages, physical, emotional, and possible sexual abuses, marital infidelity and frigidity, and insanity" (Silvio 2002: 143), showing how they "pursued" him, driving him to repeat them in $A$ Streetcar Named Desire in particular, but also to some extent in The Glass Menagerie. That this is not true only of these two plays mentioned by Silvio is shown by Philip Kolin (1998: x), for example, who stated that there was probably no dramatist who "more intimately and more incessantly inscribed his personal life within his scripts", while Harold Bloom (2000: 11) observed that "[i]n all his plays Williams would write about what he knew best: himself and his memories of his family", which seems to confirm Williams's need to never stop using his art to cope with his own life. 
In view of this, this article is an attempt to show that these two perspectives need not necessarily be kept apart. On the contrary, the thesis of the article is that The Glass Menagerie is a good example to show that linguistic repetition in dramatic plays can sometimes appear as an obsessive expression of the characters' emotions as well as those of the dramatist himself, making him repeat and relive both his experiences and his emotions. Since the following literary analysis is primarily based on repetition as a linguistic and stylistic device, it is necessary to provide an overview of repetition as a concept and its functions used as the theoretical ground of the article.

As an omnipresent phenomenon or concept, repetition takes various forms. When it comes to language, repetition can be said to naturally appear to a greater or lesser degree in almost any type of discourse due to the systemic functioning of each individual language and the limited range of words. According to Robert de Beaugrande (1991: 19), "[s]ome language elements recur simply because they are frequent in the language repertory and form small or closed sets of useful options, e.g., articles, conjunctions, and prepositions". Although elements or function words like these, bound to recur frequently in any discourse of any language, usually do not attract the attention of the readers or listeners, Deborah Tannen (2007: 83) nevertheless emphasizes the role of their frequent recurrence in "giving the discourse its characteristic shape and sound" and "establishing the shared universe of discourse created by conversational interaction in that language". However, de Beaugrande (1991: 19) highlights the importance of other repetitive elements, the ones which are not necessarily frequent in the language repertory: they attract the attention right because they are generally less frequent and their recurrence is usually deliberate or it is assumed to have a purpose and leads to certain interpretations. According to Tomaž Onič (2006: 293), the recurrence of such elements must not necessarily be deliberate or premeditated, but even when its use is the result of intuition, it potentially produces an effect on the reader/listener conveying the conscious or subconscious intention of the writer/speaker.

The pervasiveness of the latter type of repetition in various discourses has been noticed by many. Exploring the role of language in human relationships, or more specifically how ordinary conversation works to create meaning and establish relationships, Tannen attempts to show that repetition is a "fundamental, pervasive, and infinitely useful linguistic strategy" (Tannen 2007: 92), thus joining the not so small number of scholars who have recognized its importance in conversation (Tannen 2007: 34). Basing her research on a large body of tape-recorded conversations, she convincingly illustrates the pervasiveness of repetition in conversational discourse, demonstrating its automaticity linked to the basic human drive to imitate and repeat (Tannen 2007: 97-100), supported by neurological evidence. Her thesis 
is that conversational discourse provides the source for strategies which are taken up by other literary and non-literary genres, both spoken and written (Tannen 2007: 2); therefore, it is only natural to expect to find repetition in other discourses and literary forms. Indeed, many scholars pinpoint the pervasiveness of repetition elsewhere. Stating that repetition is pervasive in all types of everyday language, Shih-ping Wang points out that it is a common feature of literary discourse as well, identifying along the way an interrelation between the repetition of sound and other types of repetition (Wang 2005: 532). Seeing verbal repetition as inherent in all languages and cultures, Adnan Abdulla maintains that it pervades in religious discourse, incantations, and songs, particularly emphasizing its significance and frequency as a rhetorical feature in the Bible (Abdulla 2001: 290). As a consequence, he states, it has been frequently investigated in rhetoric, linguistics, and literary criticism (Abdulla 2001: 290), while he himself is an example proving that it has started to attract the attention of translation scholars, too. Analysing oral poetry, Finnegan views repetition as its "most marked feature" of vital importance for the definition of this literary form:

\footnotetext{
The most marked feature of poetry is surely repetition. Forms and genres are recognised because they are repeated. The collocations of line or stanza or refrain are based on their repeated recurrence; metre, rhythm or stylistic features like alliteration or parallelism are also based on repeated patterns of sound, syntax or meaning. In its widest sense, repetition is part of all poetry. This is the general background against which the prosodic and other features of oral poetry must be seen.
}

(Finnegan 1977: 90)

When it comes to dramatic discourse, which is in focus of this article, it is necessary to emphasize its specific nature and inextricable links with conversational discourse analysed by Tannen. One of the key elements of dramatic discourse is a dialogue, defined by Vimala Herman as a "mode of speech exchange among participants" (Herman 1995: 1) and, according to Joanna Thornborrow and Shan Wareing, this is what primarily distinguishes this literary form from poetry or prose - this verbal interaction and the way how it creates the world of drama, construing and negotiating its characters and their relationships (Thornborrow and Wareing 1998: 120). The dialogue and dramatic language propel action; develop intricate situations and shape characters, their personalities and their feelings, as well as their relationships. Despite being written in the first place, due to its representation of lines spoken by characters, dramatic dialogue, particularly nowadays, emulates authentic speech. However, the two are not identical but the illusion of sameness is created with the use of a limited number of linguistic features conventionally pertaining to spoken discourse (Lindquist 1995: 85), or, as stated by Herman, 
the rules and principles operating in everyday language and its general features represent resources for the construction of dramatic dialogues (Herman 1995: 6). Therefore, if repetition proves to be pervasive in conversational discourse, as previously stated, it can naturally be expected to be used by some dramatists in the creation of dialogues in their plays.

Before moving on to the functions of repetition, directly linked to the topic of this article, it is necessary to define the term itself, which can be done in various ways. It is worth stressing here that the terminology used is not entirely consistent and harmonized. In English, the concept is predominantly covered by two terms: repetition and recurrence, while it is occasionally referred to as reiteration. While Jean Boase-Beier (1994), for example, uses the term repetition, including in it all levels of language, Robert de Beaugrande and Wolfgang Dressler (1988) opt for the term recurrence, focusing mostly on the lexical elements, since, according to de Beaugrande (de Beaugrande 1991: 18), the repetition of a part of a text is rarely a real repetition, as such repetition, which he calls absolute recurrence, would have to imply the identical meaning potential, which is usually not the case. Abdulla (2001) also speaks of repetition, using it interchangeably with reiteration. In this article the term repetition is in use, which encompasses all language levels as is the case in Boase-Beier's work.

In the words of Boase-Beier, "for stylistic purposes it can be assumed that repetition involves the use of elements of language which are equivalent" but not necessarily identical (Boase-Beier 1994: 404). Quite often, this stylistic figure is based upon "the presence of an identical element repeated in contexts which vary from one another" (Boase-Beier 1994: 404), which she illustrates through rhyme, alliteration or assonance, emphasizing that repetition can also rest on other elements, not just sound. Based upon various definitions, it can be concluded that repetition can rest on an equivalence of syntactical structures, lexical elements, semantic content of certain words, and phonological elements or sounds (see Onič 2006: 293), which means that it can be syntactic, lexical, semantic or phonological. In the context of repetition in conversational discourse, Tannen makes distinctions on different criteria. She first distinguishes between self-repetition and allo-repetition (repetition of others). The second criterion - the fixity in form, in her words offers a range from exact repetition (words or statements found in the same or almost the same form) to paraphrase (similar ideas expressed differently), between which is repetition with variation, such as questions changed into statements or statements into questions, repetition with a single word or phrase changed, and repetition with change of person or tense (Tannen 2007: 63).

Repetition most frequently appears at lexical and semantic levels, the former being the most conspicuous, with a word or a group of words being repeated. 
A certain word may re-appear in the form of a different part of speech, defined by de Beaugrande and Dressler as partial recurrence (de Beaugrande \& Dressler 1988: 54-55). De Beaugrande later extends the definition to word clusters which are not entirely repeated but some elements of which are repeated in the same or similar form (de Beaugrande 1991: 19). Purely semantic repetitions are also frequent as textual devices, especially in poetry, as is observed by Boase-Beier (1994: 404), who refers to the devices of this nature as semantic chains. Apart from the words with shared elements of meaning or associations, she includes here even antonyms, which is similar to what Hoey calls complex repetition (see Toolan 2016: 56), as a way of acquiring lexical cohesion.

The mention of lexical cohesion brings us to the issue of function: notably, what functions are performed by repetition in general. Achieving lexical cohesion is certainly an important function of lexical and semantic repetition, particularly in narration, since, according to Toolan, "recurrent uses of the same content word, or of related words" conveys "a sense of the integratedness of a text" (Toolan 1998: 30). In conversation, Tannen mentions a range of functions served by repetition, such as participatory listenership, ratifying listenership, humour, savouring, stalling, expanding, participating, evaluating through patterned rhythm, and bounding episodes (Tannen 2007: 67). De Beaugrande sees its function as carrying a context-sensitive message, such as approval, insistence, anxiety, doubt, surprise, or irony (de Beaugrande 1991: 18).

However, due to the nature of this article, the functions of repetition will be viewed in the context of literary texts and their poetic effects. In literature, generally, all elements of a text, no matter whether they are a result of the author's conscious or unconscious choices, shape the text with all its specificities which create certain literary effects on the readers and guide them to specific interpretations (see Short 1996: 70-71). This can easily be linked to Basil Hatim and Ian Mason's statement that "reiteration of text items is always motivated" (Hatim \& Mason 1990: 124). In this sense, it might be felicitous to start from Boase-Beier's observation that "style of a literary text goes beyond its content to allow the text to do something besides just saying something, whereby what it does might be to echo a particular meaning in its form, or to make the reader supply a meaning" (Boase-Beier 2011: 12), since repetition is a device that makes part of that style. Focusing on poetry, Boase-Beier states that repetitions add structure but that "they contribute more substantially to meaning in that they are also frequently iconic", mirroring repetitive situations or states in the world described by the poem, which means that they may convey a "sense of constancy or lack of change", thus being their reflection (Boase-Beier 1994: 404). Abdulla starts from two basic functions, the first being the sheer joy of the sounds themselves being reiterated, but which at the same time unintentionally becomes a means of emphasis, depending on the context, while the second depends on an 
individual poet's use or intention of repetition (Abdulla 2001: 291). He states that repetition is used for emphasis, exaggeration, or the creation of parallel structures (Abdulla 2001: 302). However, in his view, one of the principle functions of this rhetorical device is "to hammer down the content" (Abdulla 2001: 290). Thus, for example, the use of repetition in the short story In Another Country by Ernest Hemingway, whose effective use of this device plays an important role in the writer's overall achievement as a master of style, highlights the general routine of characters' lives mirroring their gradual disintegration, or, in other words, "[t]he monotony of their lives expresses itself in the monotony of reiteration" (Abdulla 2001: 292). Abdulla also gives the example of Shakespeare's tragedy Othello, where the repetition of the word "farewell" in Othello's central general camp speech "hammers down both the content (the abandonment of peace) and the tone (the repetition becomes a sort of a bell that foretells the coming chaos)" (Abdulla 2001: 295).

This function seems to be closely linked to the emotive function, vital in understanding Williams's use of repetition in The Glass Menagerie. The link might be best encapsulated by Tannen's statement in which she connects cognition and emotion, speaking of both conversational discourse and literature: "Part of the effect of participating in sense-making and of being swept up by the sound and rhythm of language is emotional. The similarity between conversational and literary discourse exists because both seek not merely to convince audiences (a purportedly logical process), but also to move them (an emotional one)", after which she concludes that "[u]nderstanding is facilitated, even enabled, by an emotional experience of interpersonal involvement" (Tannen 2007: 46).

The link between repetition and emotion through what Geoffrey Leech and Mick Short referred to as "emotive heightening" of the repeated meaning (Leech \& Short 1981: 247) was noticed by Leech long ago, when he, despite seeing repetition as a not particularly sophisticated linguistic resource, accentuated its role in expressing and intensifying emotions:

\begin{abstract}
Although repetition sometimes indicates poverty of linguistic resource, it can, as we see, have its own kind of eloquence. By underlining rather than elaborating the message, it presents a simple emotion with force. It may further suggest a suppressed intensity of feeling - an imprisoned feeling, as it were, for which there is no outlet but a repeated hammering at the confining walls of language.
\end{abstract}

(Leech [1969] 1991: 79)

Leech gives an example from the well-known scene from Shakespeare's The Merchant of Venice when Shylock learns about the elopement of his daughter Jessica with a Christian, who also took some money from him, where repetition is skilfully used to intensify Shylock's dismay over losing both his daughter and some of his money. 
Jean Boase-Beier also makes reference to the emotive function, seeing it merely as a "less obvious type of iconicity" (Boase-Beier 2006: 107), only that it is in the context of sound or phonological repetition. She speaks of the phenomenon occasionally referred to as phonaesthesia, described by Anderson as sound associated with emotion (Boase-Beier 2006: 107). Relying on inputs from psycholinguistic research, she stresses the strong presence of such associations in individual languages. Some words, for example, are simply felt to be unpleasant in a language due to the association of certain sounds contained by them with unpleasant feelings. Therefore, as she observes, the repetition of these sounds through a series of words can be used to trigger a particular feeling in a text (Boase-Beier 2006: 107).

As previously stated, the emotive function in literature is closely linked to the poetic one. Despite warning that the two functions should not be confused or identified, Paul Friedrich accentuates this link, describing the specific relation between them as follows: "The main content of this relation is that the emotions are the main source or driving force for the poetic ... and hence are more powerful, or 'deeper" (Friedrich 1986: 128). Tannen, who agrees that the emotive function is not synonymous with the poetic one, also stresses that emotion is "a significant source of the language's power - its ability to fire the individual imagination" (Tannen 2007: 46). This link is the most visible in the concept of lyricism, most frequently associated with lyric poetry and generally framed through the subjectivity, artistic beauty or sensuality of expression of deep thoughts and feelings.

As suggested earlier, the poetic force and emotion, in the form of highly expressive lyricism, are both closely linked to Williams and his works (see Crandell 1996: xxv-xxvii). In his attempt to achieve "a closer approach to truth" through "expressionism and all other unconventional techniques in drama" (Williams 2000: 395), ${ }^{2}$ in the opinion of many, Williams introduced into American drama unrivalled poetry and lyricism, creating "the greatest dramatic poetry in the American language" (Griffin 1995: 13), which, deriving from a region enveloped in romantic mythology, in Christopher Bigsby's words, also derives from "characters whose struggle with the real leaves a residue of poetry in their broken lives" (Bigsby 1997: 29). In this manner, he extended the borders of theatre, combining lyricism and experimentalism which revolutionized American drama (Roudané 1997: 1). Frank Durham called him a "theatre poet in prose" (Durham 1971: 3); in Matthew Roudané's words, he is "the poet of the heart" (Roudané 1997: 1); and in Brooks Atkinson's view, "[h]e is a poet because he is aware of people and of life" (Atkinson 1996: 53).

2 See Production Notes published as a preface to The Glass Menagerie. 
Finally, Walter Kerr observes that he captures a "turn of life while it is still fluid, still immediate, before it has been sterilized by reflection" (Bloom 2000: 50).

Although Williams created his plays in line with the idea of what he termed "plastic theatre" (Williams 2000: 395), which practically meant dethroning the text by attaching equal importance to all other theatre elements, the linguistic means he used to transform reality and approach the truth through poetry and lyricism did not lose their value. On the contrary, Williams demonstrates a superb mastery of language and style, described by Arthur Miller as "rhapsodic insistence on making form serve his utterance" (Bigsby 1997: 31). Among a wide range of stylistic means employed by Williams, repetition plays a significant role. It appears in various forms and produces diverse effects, emerging as a major element in characterization and the overall construction of meaning. Fascinated by the possibilities offered by language, Williams seems to have explored its limits, discovering also new possibilities of repetition. As a result, his recurring words reverberate in the readers' minds for a long time. In the words of Martin Browne, "Tennessee Williams's use of repetition to create a prison of words is extraordinarily skilful: words beat like a tattoo on the heart, yet the beat is subtly changed at each hearing" (Browne 1957: 15).

Present in many of Williams's plays, repetition seems to be particularly prominent and meaningful in the Pulitzer Prize winning play The Glass Menagerie, which "propelled him into fame and fortune" (Silvio 2002: 135). Wherever repetition appears in this piece, emotion seems to come into play. This is evident in connection with the members of the Wingfield family, the three major characters, who appear to be permanently trapped in their feelings and frustrations. However, with the characters representing members of Williams's own family in the difficult circumstances they were trapped in, this play also seems to be a reflection of the dramatist's own emotions and frustrations expressed or intensified also through repetition. Therefore, combining the stylistic perspective with literary analysis, and at the same time taking into account the psychological insights into the link between Williams's life and work, an attempt will be made to show how the expression of the characters' and Williams's own trapped emotions is closely linked to the use of repetition as a linguistic and stylistic device. In other words, the function of repetitions as indicators of trapped emotions will be explored.

The Glass Menagerie is widely known as a story of the Wingfield family comprised of the single mother Amanda, deserted long ago by her wayward husband, and her two children, Tom and Laura, struggling with the challenges of early adulthood. Unable to provide financially for her family, which lives in reduced circumstances on her son's meagre salary in the stifling job of a warehouse clerk, Amanda attempts to ensure a brighter future for her crippled, 
socially maladjusted and hypersensitive daughter, whose "separation increases till she is like a piece of her own glass collection, too exquisitely fragile to move from the shelf" (The Glass Menagerie, 394). After a failed attempt at her education in a business college, thwarted by her daughter's inability to find motivation and fit in, Amanda obsessively resorts to finding Laura a husband as her last hope. Pressurizing Tom, the family's only link to the outside world, to provide indispensable help to her intent, she finally succeeds in having a potential suitor for Laura invited for dinner. However, after a tender and encouraging kiss, this last hope, who surprisingly turns out to be the boy with whom Laura was secretly in love in high school, is permanently dashed in a second with the visitor's revelation that he is actually engaged and unavailable. Amanda's fury at Tom bringing over the wrong person eventually pushes him over the edge and he deliberately causes his own dismissal, which he, as an aspiring poet, has craved for a long time. The entire situation reveals a whirlpool of overwhelming, complex and conflicting emotions which inhabit the individual world of each character, with repetition playing an important part in their expression.

Repetitions are of vital importance in the revelation of the emotional world and mental states of the manipulative and controlling Amanda, apparently based on Williams's mother, Edwina, who "acknowledged the similarity" (Heintzelman \& Smith-Howard 2005: 94). To begin with, Amanda frequently makes reference to jonquils, which represent her connection with her much brighter past, running parallel with the bright past of Williams's mother, who, according to Brown, "recalled that in her youth she was always 'the belle of the ball" (Heintzelman \& Smith-Howard 2005: 94) and who never stopped dreaming of grandeur. ${ }^{3}$ As Alice Griffin has rightly observed, reminiscing is an obsession with Amanda (Griffin 1995: 23-24), or, in Williams's own words, she is "clinging frantically to another time and place" (The Glass Menagerie, 394), which she repetitively reminds her children of, just like Edwina did. Thus, for her, the flowers are a reminder of her glorious past, at the same time signifying what she wishes for her daughter. And this glorious past, when she was affluent, respected, loved, hopeful and vigorous, is linked to what Thomas E. Porter described as the myth of the Old South, one of gracious living, family tradition, chivalry, and coquetry which lent a stability of time and place to those who partook of it (Porter 1969: 158).

Faced with hardship and helplessness as a single mother in a changed world, Amanda finds herself in circumstances which are a far cry from her former life and expectations, and which echo the grim financial situation of the Williams family and frequent absence of the father, a travelling salesman. Therefore, she

3 Most of the information about Williams's life was obtained from his well-known biography written by Donald Spoto (1985). 
is trapped in her own memories, illusions and, above all, emotions, personified by jonquils she occasionally mentions throughout the play. Her return to her past is but a way to escape the harsh reality, in which she is paralyzed by fear.

Jonquils are flowers which Amanda was absolutely fascinated with in the spring when she was courted by countless suitors, the so-called gentlemen callers, whose number in one particular week reached a total of seventeen. They are the flowers of her youth which represent charm and beauty. Her life was very promising then: many men wanted her and the one she chose had not left her yet. In fact, it is in this same promising summer that Amanda met and chose the man who was to change it all, just like Williams's father changed it all for his mother, bringing her poverty and misery instead of the expected happiness, well-being and prosperity. Amanda uses jonquils to decorate the flat for the arrival of the gentleman caller, who represents hope for her daughter Laura, but this brings nothing but misery: the gentleman caller abandons Laura right at the moment seemingly heralding a happy ending. Thus, Amanda's failure to find a husband for Laura is even more tragic for her as she associates it with her own husband who abandoned his family long ago, shattering all of her hopes.

The mythological symbolism of the jonquils is also important, which is related to Amanda's self-perception. Notably, the jonquil (Narcissus jonquilla) is a type of narcissus, ${ }^{4}$ the flower viewed as a symbol of vanity and selfadmiration in Western culture. The ancient Greeks believed that the flower originated from the vain young man Narcissus who pined away after falling in love with himself, or rather his own reflection in a lake. According to the Greeks, the Gods turned his posthumous remains into narcissuses. Just like Narcissus, Amanda also appears to be in love with her own image, the image from her youth, whose reflection she continuously looks for, frantically clinging to it even now. This reflection is at the same time her life and her downfall: her life because she draws her strength from it to move on and her downfall because by escaping to it, she fails to come to grips with reality in a healthy way. Therefore, the repetition of jonquils has an emotive function.

Typically, the word jonquils is repeated in emotionally charged moments. A very illustrative moment is found in Scene Six while Laura and Amanda are waiting for Tom to arrive with the long-expected visitor - the gentleman caller, another autobiographical detail based on the real Jim O'Connor invited on an occasion to the Williams home in order for him to become better acquainted with Williams's sister. Attaching disproportionate importance to this visit, Amanda has high expectations and her excitement is intense. At the same time,

The narcissus also has poetic value. A delicate and fluttery flower with mythological connotations, it is often mentioned in poetry, under different names though, such as daffodils in the well-known poems by Wordsworth and Cummings. 
the girlish frock of yellowed voile with a blue silk sash she has put on for this occasion and a bunch of narcissuses in her hand take her back to her youth, arousing in her mixed feelings. Recalling the spring when she, defying malarial fever and surrounded by suitors, enjoyed her days on outings and evenings at parties, Amanda conjures up the image of jonquils, which, symbolically, marked that spring. Feverishly, as if in a trance, she repeats the word jonquils over and over again, stopping abruptly at mentioning her husband, who stopped it all:

AMANDA: ... So lovely, that country in May. - All lacy with dogwood, literally flooded with jonquils! $!^{5}$ Jonquils became an absolute obsession. Mother said, "Honey, there's no more room for jonquils". And still I kept on bringing in more jonquils. Whenever, whenever I saw them, I'd say, "Stop! Stop! I see jonquils!" I made the young men help me gather the jonquils! It was a joke, Amanda and her jonquils! Finally there were no more vases to hold them, every available space was filled with jonquils. No vases to hold them? All right, I'll hold them myself! And then I ...met your father!

Malaria fever and jonquils and then - this - boy...

(The Glass Menagerie, 435)

After Amanda's emotional outburst, the flowers still remain in focus, establishing a link between Amanda's past and Laura's present. Amanda wishes for Laura the same things she had that spring. However, Laura's reality is different, which she symbolically shows by putting the flowers aside on the armchair. And yet, Amanda is determined to ensure at least one suitor for her daughter and therefore takes the flowers and places them in a bowl on the table.

Jonquils are not the only flowers appearing in The Glass Menagerie. Another kind recurring on several occasions and also having a symbolic meaning are Blue Roses. Although Blue Roses do not appear as frequently as jonquils, their repetition also reveals the emotional world of one of the characters - Amanda's daughter Laura, based on Williams's sister (Heintzelman \& Smith-Howard 2005: 94). However, unlike jonquils, Blue Roses do not reappear through uncontrollable repetitions within individual monologues which, in themselves, represent the emotional state of the speaker. The reason may well be found in the fact that Laura's emotional world is expressed in an entirely different manner from Amanda's. Unlike Amanda, whose feelings are expressed through endless rambling, Laura's world is mostly expressed through silence and through her play with the miniature glass figures

$5 \quad$ Repeated words in this and other passages from the play provided in block quotations in this article were made bold by the authors for the sake of emphasis. 
as a substitute for the real world and communication with people. Therefore, Blue Roses are something Laura hides deep inside her heart, mentioning them merely in the rare moments of her opening up.

Just as jonquils are linked to Amanda's promising and emotionally fulfilling girlhood and her gentleman callers, Blue Roses are connected to Laura's high school days and Jim, the boy she was infatuated with who appears as her own potential gentleman caller. Notably, the popular high school hero Jim, whom she met in the school choir, called Laura Blue Roses. The reason was the following: having come down with pleurisy, Laura stopped attending classes for a while and upon her return, when Jim asked her the reason of her absence, he misheard pleurosis as Blue Roses, calling her that name ever after. Apparently, although this was the result of a banal misunderstanding, the name Blue Roses has multiple symbolism, the repetition of which is related to Laura's fragile emotional world she is trapped in, mirroring the even more fragile emotional world of Williams's own sister. The name Blue Roses is of tremendous importance for Laura as specific proof that the boy whom she fell in love with registered her presence. Therefore, just like her mother, Laura also flees from reality into the past, the world of pleasant memories, fantasizing about this boy as the only male who has ever paid any attention to her. Thus, although Jim had a girlfriend at that time, it was the first time Laura had felt noticed and important and took enormous pleasure in his attention. In other words, this was the moment when Laura was happy, so Blue Roses are linked to her happiness.

In order to be able to discuss the other symbolic meanings of the name Blue Roses, it is necessary to refer briefly to the notion of blue rose as a flower. To begin with, the blue colour is utterly untypical of roses. In fact, it is unnatural since roses lack a gene or pigment responsible for the creation of this colour. However, since blue roses fascinated people for a long time, they tried and eventually succeeded in creating them artificially. Thus, the blue rose became a symbol of beauty, mystery and the desire to achieve the unattainable. In some cultures, a blue rose is deemed to be able to make all of the wishes of its owner come true. In Chinese folklore, a blue rose symbolizes the hope of unattainable love. In this context, it is clear that the nickname Blue Roses symbolizes Laura herself. Although Laura feels inadequate and states that "blue is wrong for roses" (The Glass Menagerie, 458), the nickname actually accentuates her delicate and unusual beauty, her isolation and her uniqueness. Laura is described as a pretty but crippled girl and yet, as Tom says, it is not just Laura's crippled state that makes her different but her nature itself (The Glass Menagerie: 430-431). Besides, Laura is presented as extremely shy, frail and overly sensitive, which is particularly highlighted in contrast with her mother's charm and extrovert personality. At the same time, through her subtlety, she is the only character in the play who would never hurt another being. Finally, 
although Laura's lines, in tune with her introvert personality, occupy the least space in the play, she is the axis that the play revolves around.

It is particularly worth emphasizing here another symbolic meaning attached to Blue Roses, obviously of an autobiographical nature: the name of Williams's own sister was Rose, and she was the central character in his life, as will be shown later in the paper. Rose's condition and her severe psychological problems made her feel extremely vulnerable and miserable, frequently making Williams himself feel very sad about her, all this giving another dimension to the epithet "blue" (sad) in Blue Roses. In this context, it is significant to stress that Williams's sister's psychological condition eventually ended in a frontal lobotomy, ${ }^{6}$ the effects of which on a patient's personality, including apathy, passivity, poor ability to function and concentrate and, above all, a "lack of initiative" (Freberg 2010: 417), can easily be traced in Laura, as a mirror character of Rose, although in the play no direct reference is made to this procedure or other related facts from Rose's life.

Two central places in The Glass Menagerie where the name Blue Roses appears are extremely emotionally charged. The first moment comes right after a heated and bitter discussion between mother and daughter following Amanda's shocking revelation that Laura has only been pretending to attend classes at the expensive business school for which Amanda cherished fervent hopes. After Amanda's outburst of anger and disappointment, in an attempt to relieve the pain inflicted on her by her mother's words, Laura unexpectedly readily accepts her question about boys and very soon starts speaking about Jim and Blue Roses:

LAURA: He used to call me - Blue Roses.

(IMAGE: BLUE ROSES.)

AMANDA: Why did he call you such a name as that?

LAURA: When I had that attack of pleurosis - he asked me what was the matter when I came back. I said pleurosis - he thought that I said Blue Roses! So that's what he always called me after that. Whenever he saw me, he'd holler, "Hello, Blue Roses!"

(The Glass Menagerie, 410)

The other central place where the whole story recurs with the repetitive mentioning of Blue Roses is also extremely emotionally charged. Notably, remaining alone in the dark with Jim during a humiliating power cut caused by the family's failure to pay the bills, and encouraged by his kindness and cordiality, Laura finally opens up recalling the minutest details of their high

6 A radical and in the 1940 s and 1950 s extremely wide-spread therapeutic measure for severely disturbed mental patients. It is defined as "a surgical procedure in which a large portion of the frontal lobe is separated from the rest of the brain" (Freberg 2010: 47). 
school encounters. With his memory stirred by these details, Jim finally manages to locate her:

\begin{abstract}
JIM: Aw, yes, I've placed you now! I used to call you Blue Roses. How was it that I got started calling you that?

LAURA: I was out of school a little while with pleurosis. When I came back you asked me what was the matter. I said I had pleurosis - you thought I said Blue Roses. That's what you always called me after that!
\end{abstract}

(The Glass Menagerie, 450)

Thus, this repetition includes the story told by Laura in an almost identical way both to her mother and to Jim himself. The reason seems quite clear: the story is of paramount importance for Laura as this was the only emotional experience with any man in her entire life. Therefore, she keeps it deep inside, feeding on it and healing herself with it in the moments when her trapped emotions culminate. Finally, the wordplay that this story, which has become a fixed structure, is based upon is not accidental either: pleurosis as a symbol of Laura's physical imperfection is replaced by Blue Roses as a symbol of something beautiful and rare.

Repetition as a linguistic device in The Glass Menagerie does not appear only in the lines of female characters. Consciously or unconsciously, Tom Wingfield, "Williams's most autobiographical character" mirroring the dramatist himself (Heintzelman \& Smith-Howard 2005: 94), also resorts to repetition, which additionally illuminates his character and his own emotional world. The words which he frequently utters are movies and adventure. Both movies and adventure appear as repetitive symbols, appearing in the moments of heightened tension and emotions. It is usually in such moments, for example, that Tom says that he is going or that he has been to the movies. Thus, the frequent recurrence of the word movies in particular clearly indicates its importance for Tom and for the overall meaning of the play.

The word movies is derived from the verb move, denoting action or a change in position, and is used to signify both films (as moving images) and the place where films are watched on a large screen. Its double meaning, together with the etymological connection with the verb move, makes this word highly suitable for poetic polysemy, which, again, suits Tom, who is a poet at heart. Thus, the word movies sublimates Tom's passion for films, his burning desire for movement and his poetic tendencies. As an aspiring poet fascinated by words, Tom explicitly uses the link between the word movies and the verb move, which is best illustrated in Scene Six, in a passage symbolically accompanied by the image of a sailing boat with a Jolly Roger:

TOM: I'm tired of the movies.

JIM: Movies! 
TOM: Yes, movies! Look at them - (A wave toward the marvels of Grand Avenue) All of those glamorous people - having adventures - hogging it all, gobbling the whole thing up! You know what happens? People go to the movies instead of moving! ...Yes, until there's a war. That's when adventure becomes available to the masses! ... Then the people in the dark room come out of the dark room to have some adventures themselves ... I don't want to wait till then. I'm tired of the movies and I am about to move!

JIM: (Incredulously) Move?

TOM: Yes.

JIM: When?

TOM: Soon!

(The Glass Menagerie, 440)

As can be seen, the link between the word movies and the verb move is set in the form of a special kind of repetition - polyptoton, the repetition of words derived from the same root (Corbett \& Connors 1999: 59). At the same time, it is also set as an antithesis, defined as the introduction of contrasting ideas, often in parallel structures (Corbett \& Connors 1999: 46), given that Tom introduces movies as passivity, while move by nature implies activity. The meaning is additionally supported by the simultaneous repetition of the word adventure connected with the verb move, as adventure necessarily involves action and moving.

For Tom, Williams's alter ego, movies are a substitute for the real life and adventure which he craves and which are in stark contrast to the suffocating situation he feels trapped in. As stated before, due to the absence of his father, Tom is forced to assume the role as provider, which has led him to the low-paid, uninspiring, menial job of a warehouse worker, mirroring the job in a shoe company Williams was forced to take by his father, which he loathes as much as Williams loathed his as it frustrates his ambitions as a poet and adventure seeker. Besides his physical confinement to his workplace, he feels trapped in the daily humdrum of his life, isolated from the rest of the world, never free to lead his life at his own discretion. As a forced breadwinner for his helpless mother and sister, he feels duty and responsibility, suffering the pangs of conscience for his overwhelming desire to escape and live as a free man. In his attempt to break free, Tom resorts to the world of fantasy, embodied in literature and films, Williams's great loves. At the end of the workday, exhausted by the dull and sluggish atmosphere of the warehouse, and unwilling to replace one depressive ambience for another, Tom regularly goes to the cinema, the only way for him to cope with the misery and anguish he feels. A poet and a dreamer, he retreats into solitude delving into the world of adventure movies. He explicitly states his fondness for adventure: "I go to the movies because - I like adventure. Adventure is something I don't have much of at work, so I go to the movies" (The Glass Menagerie, 421). Just like, as he says, the entire country lives the life of illusion, finding solace in movies, glamorous 
magazines, hot swing music, dance and sex, he himself finds refuge and solace in a world of adventure movies, where he wins a tiny piece of freedom. Therefore, whenever he is pressurized and feels trapped, he obsessively mentions movies as his only relief, even for a brief moment. It is through this repetition that we experience the depth of his frustrations and trapped feelings.

But since after watching a movie Tom must get out and face reality again, his escape into the world of movies does not solve his problems; and neither do jonquils for Amanda nor Blue Roses for Laura. Their repetition just highlights their anxieties and their confinement, and confinement and escape are often seen as the major themes and central motifs in The Glass Menagerie (see Bloom 2000: 69; Kolin 1996: 36). What signals a hope of salvation, however, is another repetition - the repetition of the phrase gentleman caller, mostly found in Amanda's lines. Despite being linked to Amanda's obsessive adherence to her glorious past and the armies of her own suitors, this repetition also accentuates a real-life chance of salvation, a genuine way out for everybody (see Kusovac 2009: 3-4). The gentleman caller here symbolizes the potential chance of finding a husband for Laura as a last resort after her failure at the business school which was to provide her with an opportunity for independence. In fact, in Tom's words, it was after this failure that Amanda became obsessed with it: "Like some archetype of the universal unconscious, the image of the gentleman caller haunted our small apartment ... An evening at home rarely passed without some allusion to this image, this spectre, this hope" (The Glass Menagerie, 410).

Indeed, although it is Amanda's emotional state and hopes that are highlighted through her obsessive repetition of this phrase, the gentleman caller indirectly reflects the feelings and hopes of all the three members of the Wingfield family, as a husband for Laura could bring salvation to all: Laura might ensure self-realization and a more fulfilling future, Tom would be relieved of the burden of his duty and free to pursue his own dreams, and Amanda's mission as a mother would be accomplished. However, the play does not have a happy ending. The gentleman caller Tom has brought home for dinner proves to be unavailable and inaccessible to Laura: he is engaged to be married, which leaves Laura humiliated and in dismay after she has allowed his kindness to spark a ray of hope in her. She is crushed, and so is Amanda. There is no hope left. Unable to cope with the burden of guilt imposed on him by Amanda, Tom arranges his own dismissal by writing a poem on a box of shoes and goes away, leaving his mother and sister behind. However, he does not find peace. At the end of the play, we find him permanently trapped in his feelings of love, guilt and duty: "Oh Laura, Laura, I tried to leave you behind me, but I am more faithful than I intended to be! I reach for a cigarette, I cross a street, I run into the movies or a bar, I buy a drink, I speak to the nearest stranger anything that can blow your candles out" (The Glass Menagerie, 465). 
At this point it is worth making a connection with the emotions of the dramatist himself, his motives and needs behind writing this play, as well as their expression or intensification through repetition. In order to do this, it is necessary to refer briefly to the psychological theoretical background which is of particular importance for this connection. A relevant and widely recognized concept, which "has received surprisingly little systematic exploration" (Van der Kolk 1989: 389), is repetition compulsion, formally noted by Freud and reflecting the phenomenon that "[m]any traumatized people expose themselves, seemingly compulsively, to situations reminiscent of the original trauma" (Van der Kolk 1989: 389). Speaking of the unconscious, Freud stated that a traumatized person was bound to "repeat the repressed material as a contemporary experience instead of ... remembering it as something belonging to the past" (Freud 1962: 18). According to him, the past can be relived through memories and actions, and actions represent behavioural re-enactment. But reenactment can also take the form of dreams in which memories and emotions are repeated, or literature for that matter, which adds to the diversity of these phenomena. Although clinical experience shows that repetition causes further suffering (van der Kolk 1989: 389), Freud believed that the aim of repetition was to gain mastery.

Another relevant theoretical input comes from Jacques Lacan, who, extending Freud's theory of the unconscious, added another crucial element that of language, stating that "the unconscious is structured like a language" (Miller 1998: 20). Thus, he treats the unconscious as a language, a form of discourse, leading us to the world of endless signifiers where the signified is of secondary importance. His concepts of metaphor and metonymy are crucial here. Metaphor "freezes and privileges repressed signifiers", leaving them active but restricted to their own realm and no longer subject to change, while metonymy "ensures ... that the repressed term always remains in associative relations to the rest of the subject's language, explaining how the unconscious is able to intervene into or speak through consciousness at symptomatic moments. It enables the links between the unconscious terms, their preconscious/ conscious representatives, and networks of free associations to be unravelled enough to facilitate interpretation" (Grosz 1990: 100-101). And this is exactly what makes the link between Williams's and his characters' emotions and their use of linguistic repetition.

As stated before, Williams presented himself in the character of Tom, whose name resonates with the dramatist's own given name - Thomas. Just like Tom, and the other two main characters for that matter, Williams is trapped in his own traumatic experience and circumstances, as well as the emotions triggered by them. His first traumatic experience comes from his childhood, where he grew up as one of three children born in a troubled marriage filled with rancour, 
with a cold, unloving and abusive father and resentful and controlling mother. His father, Cornelius, was particularly problematic for his emotional growth and stability as he was utterly unable to provide his children with the necessary love, support and security, particularly Tennessee and his sister Rose, who did not live up to his stereotypical expectations. Thus, the two of them were disparaged, ridiculed and rejected by their father. A sensitive soul inclined to poetry, Williams himself was mocked for his alleged failure to be manly enough, while his sister Rose was severely judged for her extreme selfconsciousness, inhibitions and vulnerability. The lack of understanding and acceptance for Williams culminated in his father's decision to stop supporting his university education, forcing him to work in a shoe factory, which he left a year later due to the nervous breakdown he suffered and which left a deep imprint on his life, finding a way into The Glass Menagerie, too.

However, Williams's deepest frustration and trauma from his young age seem to be related to his sister Rose. Apparently, the joint abuse and rejection by their father as well as the accompanying suffering, created a particularly strong bond and sense of togetherness between the two inseparable siblings, which excluded their brother Dakin, who, being a tough man like his father, was the only child Cornelius was fond and proud of. As previously noted, Williams's sister Rose was an extremely vulnerable and fragile person suffering from increasing mental disorientation and emotional instability, and who was allegedly even sexually abused by her father. As Williams approached young adulthood and went to university, Rose's condition deteriorated, causing her increasing mental pain and anguish, requiring psychiatric treatment and frequent admissions to mental hospitals. Thus, while Williams was going through the happiest period of his life, surrounded by friends and devoting himself to writing away from the conflicts and tensions of his family, his sister was struggling with her illness without the support of her loving brother, which started to increasingly prick Williams's conscience. In Silvio's words, he and Rose began to grow apart with the rapid progression of her illness and "he felt the increasing strain of being asked to look for her" (Silvio 2002: 141). Eventually, while Williams was at another university seeking peace in obsessive writing, Rose was subjected to a lobotomy without his knowledge, which dealt a crushing blow to him. As Donald Spoto noted, "[f]rom then on, the spirit of his sister haunted his life, her personality trapped in a childish permanence like a pinned butterfly. From his earliest one-act plays in 1938 to the end of his life, the name and image of Rose and her beloved roses pursued him" (Spoto 1985: 60). Silvio also emphasizes the deep and lasting imprint the tragic situation with Rose left on Williams, causing him "internal chaos and anguish" which he tried to make bearable through compulsive and obsessive writing, promiscuity and incessant movement, and which "could only be momentarily quieted through 
the use of psychic defences that wore thin and exacted their own adverse consequences" (Silvio 2002: 142).

As can be seen, on the level of the plot and characters, the parallels with the play are numerous and obvious. However, it is also obvious that some of the most delicate and most painful details were left out or changed. For example, in The Glass Menagerie the actively abusive father was turned into an absent figure being abusive through abandonment only, while Rose's progressive mental illness was transformed into a physical deformity accompanied by heightened sensitivity, with no mention of her obsession with her father's alleged sexual overtures, for example, which eventually led to such a radical and detrimental surgical procedure as a lobotomy. According to Silvio, these more upsetting confessions were made in Williams's later masterpiece, $A$ Streetcar Named Desire, where the darkest elements of his family life were exposed in fragments through different characters and different situations. And Silvio is right in that $A$ Streetcar Named Desire was more revealing in terms of violence, sexual decadence and lunacy, but The Glass Menagerie is a strong and truthful confession of the playwright's trapped emotions, as well as the essential emotions of the members of his family. Thus, rather than being "a gentle lament for missed opportunities", as described by Spoto (1985: 112), The Glass Menagerie is a powerful poetic statement of the emotional worlds of the characters and, above all, of the dramatist himself. Here it is worth emphasizing that the play is set through the prism of Tom as a poet and narrator, thanks to whom it emerges as a poetic memory play in which Tom is Williams himself. So Tom, or Williams, is the one who makes a confession but at the same time the one who orchestrates it all. Thus, all elements, including repetitions, are but the product of Tom's poetic vision, which creates a tension between the objectively presented dramatic truth and its representation distorted through the memory influenced by emotions.

Viewed in the context of his own emotional confession, with the unconscious working its way into language, repetitions in The Glass Menagerie apparently emerge as not only the expression of Williams's characters' but also of his own frustrations, anxieties and hopes. For not only did he appear to feel the compulsion to "repeat the repressed material as a contemporary experience" (Freud 1962: 18) in his attempt to repress a trauma, but he also seems to have unconsciously resorted to repetition as a linguistic and stylistic device to relive these experiences or, in Lacanian terms, his unconscious spoke through consciousness at symptomatic moments, with networks of free associations unravelled enough to facilitate interpretation (Grosz 1990: 100-101). Thus, to quote Browne, he created a "prison of words" which "beat like a tattoo on the heart" (Browne 1957: 15), revealing his unconscious. In this context, we may well read the repetitive gentleman caller, for example, as the manifestation of 
Williams's own unconscious anguished cry for a miraculous solution to his sister's tormenting condition and for his own liberation from the never-ending agony of guilt and conscience. Moreover, all other repetitions, highlighting the feelings of individual characters as alter egos of the dramatist and his own family members, seem to reflect his unconscious struggle to gain mastery over psychological and emotional problems, adding to this prison of words and emotions, beating on the hearts of both him and his audience.

\section{REFERENCES}

\section{PRIMARY SOURCES}

Williams, Tennessee. 2000. The Glass Menagerie. In Tennessee Williams, Plays 1937-1955, 393-465 (Literary Classics of the United States). New York: The Library of America.

\section{SECONDARY SOURCES}

Abdulla, Adnan K. 2001. Rhetorical repetition in literary translation. Babel 47(4). 289-303.

Atkinson, Brooks. 1996. Streetcar tragedy: Mr. Williams' report on life in New Orleans. In George Crandell (ed.), The critical response to Tennessee Williams, 52-58. London: Greenwood Press.

Beaugrande, Robert de \& Wolfgang U. Dressler. 1988. Introduction to text linguistics. Harlow: Longman.

Beaugrande, Robert de. 1991. Coincidence in translation: Glory and misery again. Target 3(1). $17-53$.

Bigsby, C. W. E. 1997. Entering The glass menagerie. In Matthew C. Roudané (ed.), The Cambridge companion to Tennessee Williams, 29-44. Cambridge: Cambridge University Press.

Bloom, Harold (ed.). 2000. Tennessee Williams. Broomall: Chelsea House Publishers.

Boase-Beier, Jean. 1994. Translating repetition (Aspects of translation). Journal of European Studies 24(4). 403-407.

Boase-Beier, Jean. 2006. Stylistic approaches to translation. Manchester, UK: St. Jerome Publishing.

Boase-Beier, Jean. 2011. A critical introduction to translation studies. London: Continuum.

Browne, Martin E. 1957. Editorial note. Cat on a hot tin roof. London: Penguin Books.

Corbett, Edward P. J. \& Robert J. Connors. 1999. Style and statement. Oxford: Oxford University Press.

Crandell, George W. (ed.). 1996. The critical response to Tennessee Williams. London: Greenwood Press.

Durham, Frank. 1971. Tennessee Williams, theatre poet in prose. South Atlantic Bulletin 36(2). 3-16. 
Finnegan, Ruth. 1977. Oral poetry: Its nature, significance, and context. Cambridge: Cambridge University Press.

Freberg, Laura A. 2010. Discovering biological psychology. 2nd edn. Belmont, CA: Wadsworth.

Freud, Sigmund. 1962. Beyond the pleasure principle. In James Strachey (ed.), The standard edition of the complete psychological works of Sigmund Freud, vol. 18, 3-64. London: Hogarth Press.

Friedrich, Paul. 1986. The language parallax: Linguistic relativism and poetic indeterminacy. Austin, TX: University of Texas Press.

Griffin, Alice. 1995. Understanding Tennessee Williams. Columbia, SC: University of South Carolina Press.

Grosz, Elizabeth. 1990. Jacques Lacan: A feminist introduction. London: Routledge.

Hatim, Basil \& Ian Mason. 1990. Discourse and the translator. London \& New York: Longman.

Heintzelman, Greta \& Alycia Smith-Howard. 2005. Critical companion to Tennessee Williams. New York: Checkmark Books.

Herman, Vimala. 1995. Dramatic discourse: Dialogue as interaction in plays. London: Routledge.

Isaac, Dan. 1965. Big Daddy's dramatic word strings. American Speech 40(4). 272-278.

Kerr, Walter. 1996. A secret is half-told in fountains of words. In George W. Crandell (ed.), The critical response to Tennessee Williams, 118-120. London: Greenwood Press.

Kolin, Philip C. (ed.). 1996. Tennessee Williams: A guide to research and performance. London: Greenwood Press.

Kusovac, Olivera. 2009. The gentleman caller in the context of $21^{\text {st }}$ century Europe: Translation of Tennessee Williams's symbols into Serbian. Maribor International Review 2(1). 1-9.

Leech, Geoffrey. [1969] 1991. A linguistic guide to English poetry. London \& New York: Longman.

Leech, Geoffrey \& Mick Short. 1981. Style in fiction: A linguistic introduction to English fictional prose. London: Longman.

Lindquist, Yvonne. 1995. Spoken language in literary prose - A translation problem. In Peter Jansen (ed.), Translation and the manipulation of discourse, 79-106. Leuven: CETRA.

Miller, Arthur. 1987. Timebends. New York: Grove Press.

Miller, Jacques-Alain (ed.). 1998. The seminar of Jacques Lacan, Book XI: The four fundamental concepts of psychoanalysis. Trans. Alan Sheridan. New York: W.W. Norton \& Company.

Onič, Tomaž. 2006. Translating recurrences in Pinter's plays. ELOPE 2(1-2). 293-299.

Porter, Thomas E. 1969. Myth and modern American drama. Detroit: Wayne State University Press.

Roudané, Matthew C. (ed.). 1997. The Cambridge companion to Tennessee Williams. Cambridge: Cambridge University Press.

Short, Mick. 1996. Exploring the language of poems, plays and prose. London: Longman.

Silvio, Joseph R. 2002. A Streetcar Named Desire - Psychoanalytic perspectives. The Journal of the American Academy of Psychoanalysis 30(1). 135-144.

Spoto, Donald. 1985. The kindness of strangers: The life of Tennessee Williams. New York: Da Capro Press.

Tannen, Deborah. 2007. Talking voices: Repetition, dialogue, and imagery in conversational discourse. Cambridge: Cambridge University Press. 
Thornborrow, Joanna \& Wareing, Shan. 1998. Patterns in language: An introduction to language and literary style. London: Routledge.

Toolan, Michael. 1998. Language in literature. London: Hodder.

Toolan, Michael. 2016. Making sense of narrative text: Situation, repetition, and picturing in the reading of short stories. London: Routledge.

van der Kolk, Bessel A. 1989. The compulsion to repeat the trauma: Re-enactment, revictimization, and masochism. Psychiatric Clinics of North America 12(2). 389-411.

Wang, Shih-ping. 2005. Corpus-based approaches and discourse analysis in relation to reduplication and repetition. Journal of Pragmatics 37(4). 505-40. 